constitutionally sound. It assures to the federal government a necessary power less likely to be subject to the abuses which have characterized California's efforts in this area. If discriminatory statutes are necessary, let them be based on considerations of national welfare and not on the racism and narrow economic or political considerations which have motivated state action denying special classes of aliens the right to hold land.

\title{
COMMON-LAW REGULATION OF THE IDEA MARKET
}

The tremendous commercial value of ideas today is perhaps nowhere so apparent as in the motion picture, radio, and advertising industries. ${ }^{x}$ An "idea" that a musical comedy should have its scene set at Mackinac Island instead of Hawaii may be sufficient to cause the investment of hundreds of thousands of dollars and to make possible a gross profit in the millions. An "idea" that it would be desirable to abbreviate an advertising slogan for a popular-brand cigarette may result in a few cryptic letters being printed in countless issues of newspapers and magazines and being drummed into the ears of innumerable cigarette consumers via radio. Someone's suggestion that it would be a good idea to broadcast a disc jockey on a nation-wide radio hookup has consequences that are measurable in large sums. While the bulk of these ideas is probably originated within the studios and professional agencies, ${ }^{2}$ a number are developed independently by professional free-lance writers and casual amateurs. These in turn are submitted to the industry in the abbreviated form of sketches and outlines. The extraordinary value which is placed upon minor variants of an idea and the striking similarity between such variants create complex problems in the marketing of ideas. These problems arise both from the possibility of literary piracy on the one hand and from the danger of spurious claims on the other.

The copyright laws do not solve the problem, since their protection is confined to authors whose material has been published, ${ }^{3}$ while controversy in these cases springs from charges that unpublished material has been pirated. But the common law has long recognized an author's property right to his creation even before publication. ${ }^{4}$ This protection is independent of ${ }^{5}$ and unaffected by 1947).

${ }^{x}$ See Johnston v. Twentieth Century-Fox Film Corp., 187 P. 2d 474, $47^{8}$ (Cal. App.,

= The experience of radio station WGN, Chicago, seems to be typical of the entire field. With rare exceptions, unsolicited ideas have been independently developed by professionals working for the station.

3 "The statutory right is of no value, unless there is a publication. . . "Brandeis and Warren, The Right to Privacy, 4 Harv. L. Rev. I93, 200 (1890).

4 See Caliga v. Inter-Ocean Newspaper Co., 2I5 U.S. I82, I88 (Igog); Bobbs-Merrill Co. v. Straus, 210 U.S. 339, 346 (1908); Wheaton v. Peters, 8 Pet. (U.S.) 591, 657 (1834); Frohman v. Ferris 238 Ml. 430, 435 (rgog), aff'd 223 U.S. 424 (rgI2). Cf. Cal. Civ. Code (Deering, I94I) $\$ 8980,983$.

5 See Paige v. Banks, I3 Wall. (U.S.) 608, 6r4 (1871); Little v. Hall, I8 How. (U.S.) 165, 170 (1855). 
the copyright laws. ${ }^{6}$ The theoretical foundation of relief is twofold: suit on the tort theory of appropriation of literary property, or suit on the basis of an express or implied contract arising from the manner in which the defendant gained access to the material.

The essential elements of proof under both theories are the same. In seeking to persuade the court that his material was in fact copied ${ }^{7}$ the complainant must of course establish similarity. ${ }^{8} \mathrm{He}$ must also prove that his idea is novel. 9 Ideas which are common property cannot become the subject of an exclusive right. xo $^{\circ}$ Thus, a plaintiff who had recommended filming short movie features about unusual occupations was denied recovery on the thesis that, since similar films had been previously produced, his idea was not unique. ${ }^{\text {Ix }}$ Furthermore, the plaintiff must establish that the defendant had access to his work. ${ }^{\mathrm{I2}}$ It is of course evident that a successful action cannot be maintained if the defendant created or obtained his composition independently of the plaintiff. ${ }^{{ }^{3}}$ The courts have observed that recurrence is not an inevitable badge of plagiarism. ${ }^{74}$ Access may be inferred from similarity, ${ }^{15}$ but there is no necessary logical relationship. ${ }^{16}$

6 "Nothing in this title shall be construed to annul or limit the right of the author or proprietor of an unpublished work, at common law ... to prevent the ... use of such unpublished work without his consent. ..." 6I Stat. 652 (I947), I7 U.S.C.A. \& 2 (Supp., I948).

7 Aside from the allegation of a contract, there is one subtle distinction between the two theories. In the appropriation cases the plaintiff seeks damages for the unauthorized use of the material, while in the contract cases the plaintiff does not complain of any unauthorized use but seeks damages for failure of the defendant to offer compensation.

${ }^{8}$ Similarity sufficient to establish copying may be found to exist if "the two works, when compared, show such pronounced similarities of substantial... protectible material." Barsha v. Metro-Goldwyn-Mayer, 32 Cal. App. 2d 556, 56r, 90 P. 2d 371 (I939). "If dissection rather than observation is required to discern any resemblance, there is no piracy." Golding $v$. RKO Radio Pictures, Inc., I93 P. 2d I53, I62 (Cal. App., I948). But it is not necessary that the works be exactly similar. Sheldon v. Metro-Goldwyn-Mayer, 8I F. 2d 49, 56 (C.C.A. 2d, I936); see Stanley v. CBS, I92 P. 2d 495, 506 (Cal. App., I948); Universal Pictures Co. v. Harold Lloyd Corp., 162 F. 2d 354, 361 (C.C.A. 9th, 1947); Barsha v. Metro-Goldwyn-Mayer, 32 Cal. App. 2d 556, 562, go P. 2d 37r, 374 (1939).

9 Plus Promotions, Inc. v. R.C.A. Mfg. Co., 49 F. Supp. Ir6 (N.Y., I943); Liggett \& Meyer Tobacco Co. v. Meyer, ror Ind. App. 420, 194 N.E. 206, 210 (1935); Soule v. Bon Ami Co., 2or App. Div. 794, I95 N.Y. Supp. 574, 576 (1922), aff'd 235 N.Y. 609, 139 N.E. 754 (1923); Lueddecke v. Chevrolet Motor Co., 70 F. 2d 345, 348 (C.C.A. 8th, I934); DeFilippis v. Chrysler Corp., 53 F. Supp. 977, 980 (N.Y., I944); Comm'r v. Affiliated Enterprises, Inc., I23 F. 2d 665, 667 (C.C.A. Ioth, I94I).

ro See Wilkie v. Santly Bros., 9r F. 2d 978, 979 (C.C.A. 2d, 1937); Soule v. Bon Ami Co., 20I App. Div. 794, I95 N.Y. Supp. 574, 576 (1922), aff'd 235 N.Y. 609, 139 N.E. 754 (1923).

II Futter v. Paramount Pictures, Inc., 69 N.Y.S. 2d 438 (I947).

${ }^{2}$ See Twentieth Century-Fox Film Corp. v. Dieckhaus, I53 F. 2d 893, 894 (C.C.A. 8th, 1946), cert. den. 329 U.S. 716 (1946); Tamas v. Twentieth Century-Fox Film Corp., 25 N.X.S. 2d 899, 900 (I94I).

${ }^{13}$ See Wilkie v. Santly Bros., 9I F. 2d 978, 979 (C.C.A. 2d, 1937).

${ }^{14}$ See Futter v. Paramount Pictures, Inc., 69 N.Y.S. $2 d 438$ (I947); Darrell v. Joe Morris Music Co., Ir3 F. 2d 8o (C.C.A. 2d, I940).

is Wilkie v. Santly Bros., 9 I F. 2d 978, 979 (C.C.A. 2d, I937).

${ }^{16}$ Similarity may not be adequate to establish access if there is direct evidence indicating no access or if the material is such as is likely to recur spontaneously. Twentieth Century-Fox 
The access question is most acute in those cases where the idea has been channelled through a writer's agent, and conversely it is likely to be no problem in those cases where the material involved was directly submitted to the defendant.

But not all ideas will be shielded even though similarity, novelty, and access are proved. The courts will act to protect the author only if a "concrete combination of ideas" has been appropriated. ${ }^{27}$ This concept is double-barrelled. It seeks to differentiate ideas according to completeness. Thus a rough outline of a projected film is not concrete, though a script may be. And it attempts to distinguish between a single idea and a combination of ideas. Scene, plot, characters, are component parts of a work which are not protected. It is only when they are "combined" into a whole that relief for appropriation will be granted. ${ }^{x 8}$

Film Corp. v. Dieckhaus, 153 F. 2d 893 (C.C.A. 8th, 1946), cert. den. 329 U.S. 716 (1946); Darrell v. Joe Morris Music Co., II3 F. 2d 80 (C.C.A. 2d, x940).

${ }^{27}$ Stanley v. CBS, 192 P. 2 d 495 (Cal. App., I948); Thomas v. R. J. Reynolds Tobacco Co., 350 Pa. 262, 38 A. 2d 6r (1944); Plus Promotions, Inc. v. R.C.A. Mfg. Co., 49 F. Supp. Ir6 (N.Y., 1943); Stone v. Liggett \& Myers Tobacco Co., 260 App. Div. 450, 23 N.Y.S. 2d 2 ro (1940); Williamson v. New York Central Ry. Co., 258 App. Div. 226, r6 N.Y.S. 2d 217 (1939); Downes v. Culbertson, I53 Misc. 14, 275 N.Y. Supp. 233 (I934).

Confusion may be created by those courts which insist that only the "expression" or "representation" of a work will be protected. O'Brien v. RKO Radio Pictures, Inc., 68 F. Supp. I3 (N.Y., I946); Bowen v. Yankee Network, 46 F.Supp. 62 (Mass., I942); Moore v. Ford Motor Co., 28 F. $2 d 529$ (D.C.N.Y., I928), aff'd 43 F. 2d 685 (C.C.A. 2d, I930); Thompson v. Famous Players-Lasky Corp., 3 F. 2d 707 (D.C. Ga., I925); Fendler v. Morosco, 253 N.Y. 28I, I7X N.E. 56 (1930); Schubert v. Columbia Pictures Corp., I89 N.Y. Misc. 734, 72 N.Y.S. 2d 851 (1947); Barsha v. Metro-Goldwyn-Mayer, 32 Cal. App. 556, 90 P. $2 d$ 37I (1939); Cal. Civ. Code (Deering, I94I), \& 980. These terms are employed interchangeably with the phrase "concrete combination of ideas," but they tend to suggest that precise similarity is a prerequisite to successful litigation. A requirement of identity as to language could easily be avoided. Accordingly the courts have looked beyond the language used to a comparison of the combination of ideas.

I8 However, a mere idea that appears to be neither developed nor a combination may be sold under an express contract drawn before disclosure, if the idea is both new and valuable. See Soule v. Bon Ami, 201 App. Div. 794, r95 N.Y. Supp. 574 (r922), aff'd 235 N.Y. 609, I39 N.E. 754 (1923), in which an express contract to pay half of the increased profits for an idea to raise wholesale prices was held not valuable information as specified in the contract. See Masline v. N.Y., N.H. \& H. Ry. Co., 95 Conn. 702, I12 Atl. 639 (I92I), criticized in I9 Mich. L. Rev. 874 (r92r) on the ground that adequacy of consideration should not be questioned if the idea is regarded at the time the contract is made as the equivalent of the promise.

It has been suggested that abstract ideas should be capable of sale under implied in fact contracts and that their reasonable value should be recoverable in quasi-contractual actions. Ideas as Subject Matter of Express, Implied in Fact, and Implied in Law Contracts, 3 I Corn. L. Q. $382,385,390$ (1946); 40 Ill. L. Rev. 130 (I945), noting Grombach Productions, Inc. v. Waring, 293 N.Y. 609,59 N.E. $2 d 425$ (1944); 36 Col. L. Rev. 1375, r377 (1936), noting Ryan \& Associates v. Century Brewing Ass'n, I85 Wash. 600, 55 P. $2 \mathrm{~d}$ I053 (I936). There is also some evidence of a tendency to relax the requirement of a "concrete combination" in the implied contract suits. Compare Yadkoe v. Fields, 66 Cal. App. 2d 150, 15I P. 2d 906, 910 (r944), an implied contract case with Stone v. Liggett \& Myers Tobacco Co., 260 App. Div. 450, 23 N.Y.S. $2 d 210$ (1940), an appropriation case. It is submitted that neither the suggestion nor the trend is wise. The problem under both theories is the same: Has protectible material been pirated? Plaintiffs normally proceed under an implied contract theory when they have sub- 
The cases, which are in hopeless confusion, illustrate the difficulties in applying this concept. An idea that a motion picture be built around the story of the Palace Theatre in New York, coupled with four brief suggestions for story treatment, was held insufficiently concrete..$^{x 9} \AA$ written suggestion that defendant company produce and distribute to its customers a graph of the direction in which the hair on an individual's face grows was held too abstract..0 And a proposal that defendant advertise that its cigarettes burned approximately twice as long as competing brands was held to warrant no compensation. ${ }^{2 x}$ By contrast, a letter embodying an idea for an advertisement in which a wellgroomed gentleman offers a cigarette to his colleague who was to spurn the offer with the remark, "No thanks, I smoke Chesterfields," was held sufficiently concrete..$^{22}$ And a program outline entitled "Racketeer and Co." containing plans for a radio show featuring a district attorney at war with the underworld was held protectible in a suit against the producers of "Mr. District Attorney.".23

A 1948 California decision ${ }^{24}$ exemplifies the judicial process in these cases. The plaintiff who had submitted a format, sample script, and recording of a drama program to the defendant, alleged piracy in a suit based on breach of an implied contract. Judgment was entered for the plaintiff by a court which found substantial similarity not in the actual text of defendant's program but in its combination of ideas. The court found that the two program formats were similar in that in each:

mitted unsolicited material to the defendants with a request for payment. These cases are not sufficiently different from situations where the defendant has had no direct contact with the plaintiff to warrant two definitions of concreteness.

19 O'Brien v. RKO Radio Pictures, Inc., 68 F. Supp. I3 (N.Y., I946); cf. Shubert v. Columbia Pictures Corp., I89 Misc. 734, 72 N.Y.S. $2 \mathrm{~d} 851$ ( 1947 ). But judgment for the plaintiff, in a suit for appropriation, was affirmed where the composition in question was a motion picture scenario. Thompson v. Famous Players-Lasky Corp., 3 F. 2d 7o7 (D.C. Ga., I925); cf. Barsha v. Metro-Goldwyn-Mayer, 32 Cal. App. 2d 556, 90 P., $2 d$ 37x (I939); Golding v. RKO Radio Pictures, Inc., I93 P. 2d I53 (Cal. App., I948).

${ }^{20}$ Alberts v. Remington Rand, Inc., I75 Misc. 486, 23 N.Y.S. 2d 892 (1940).

2x Thomas v. R. J. Reynolds Tobacco Co., 350 Pa. 262, 38 A. 2d 6r (I944).

22 Liggett \& Meyer Tobacco Co. v. Meyer, ror Ind. App. 420, I94 N.E. 206 (I935). For comments on this case, see Logan, Legal Protection of Ideas, 4 Mo. L. Rev. 239, 256 (1939); 44 Yale L.J. I269 (1935).

Compare Healey v. R. H. Macy \& Co., Inc., 251 App. Div. 440, 297 N.Y. Supp. 165 (I937), aff'd 277 N.Y. 681, I4 N.E. $2 d 388$ (I938) (slogans and ideas for Christmas advertising campaign protected); Ryan \& Associates, Inc. v. Century Brewing Ass'n, $x 85$ Wash. 600, 55 P. 2d I053 (I936) (slogan "The Beer of the Century" protected). Although the Ryan case was brought on a theory of quantum meruit for services rendered, a decision that the slogan was concrete was essential to the result. See Soclow, The Law of Radio Broadcasting 956 (I939), for the suggestion that the case represents a turning toward the view that there is property in an idea.

${ }^{23}$ Cole v. Phillips H. Lord, Inc., 262 App. Div. I16, 28 N.Y.S. 2d 404 (I94I). On new trial, judgment was entered for defendant on the ground that the material was not novel.

${ }^{24}$ Stanley v. CBS, I92 P. 2d 495 (Cal. App., 1948). 
the program was entitled "Hollywood Preview"; the title was repeated and emphasized throughout the production; the announcer introduced the master of ceremonies; the latter was prominent in motion pictures; he stated the title of the play and the name of the star; the drama was presented; it was a play not previously seen in motion pictures; its authors were named; listeners were asked to express their opinions of the play.25

Most of these items of identity are commonplace and could readily have been independently created by the defendant, but the court asserted that a "new or different combination of ideas will be protected against piracy [and] that commonplace materials may be made into a novel arrangement. . . " 26

The ambiguity of the concepts with the concomitant uncertainties of litigation, the absence of any rule for measuring damages, ${ }^{27}$ and the threat of blackmail and nuisance suits has led the "hot idea" industry to develop self-protection devices. Unless a release has been executed, for example, radio stations and advertising agencies follow a general policy of returning unexamined the unsolicited ideas that come to them. The releases normally empower the station or agency to determine the originality of the material, the use to which it will be put, and the extent of the compensation which will be awarded. Some releases include a promise to indemnify the agency against any claims for libel, slander, infringement of copyright, violation of civil rights, and rights of privacy which may arise from use of the material. Other instruments of industry selfregulation have also been established. The Title Registration Committee of the Motion Picture Association of America settles by arbitration any disputes over similarities in film titles. ${ }^{28}$ The Screen Writers' Guild provides a registration service to aid authors in establishing the completion dates and identity of their literary property. The Guild may also arbitrate charges of plagiarism arising between its members. ${ }^{29}$

But these devices cannot avoid or settle all disputes, and the resulting cases reflect the judicial attempt to reconcile the conflicting interests within the "hot idea" industry. The rationale for protecting the originator of a "hot idea" is not the same as that invoked for protecting a party whose copyright has been infringed. Copyright holders are shielded in the interest of stimulating artistic creativity. "Hot ideas," on the other hand, rarely constitute a valuable contri-

${ }^{25}$ Ibid., at 500 .

${ }^{2}$ Tbid., at 505 .

${ }^{27}$ In Yadkoe v. Fields, 66 Cal. App. 2d I50, I5 I P. 2d 906 (I944), the damages were $\$ 8,000$; in Stanley v. CBS, I92 P. 2d 495 (Cal. App., I948), $\$ 35, \infty 0$; and in Golding v. RKO Radio Pictures, I93 P. 2 d r53 (Cal. App., 1948), \$25,000.

${ }^{28}$ Memoranda of the Title Committee of the Motion Picture Ass'n of America, Inc., as amended to October 25,1937 (mimeo).

${ }^{29}$ It has been suggested that all disputes in this field be submitted to arbitration. New Trends in the Protection of Ideas for Radio Programs, Io Air I. Rev. 394, 404 (1939); Seidenberg, An Idea about Ideas, I Arbitration in Action ro (1943). Although it is unlikely that boards of arbitration could apply standards different from those employed by the courts, their more expert knowledge of the industries would probably enable them to reach more satisfactory decisions. 
bution to the culture of the community..$^{30}$ Nevertheless, the doctrine of unjust enrichment compels the conclusion that judicial relief should be available to the originator of material which has been appropriated. By the same token agencies are entitled to protection against blackmail and honest but unfounded claims. The present framework of common-law protection of "hot ideas" could probably be strengthened if litigation were discouraged through statutes similar to the federal copyright provisions, which impose reasonable attorneys' fees as part of the unsuccessful litigant's costs. ${ }^{3 x}$ In addition where the material is unsolicited the requirements of "concrete combination" and novelty should be strictly enforced against the possibility of invalid claims. However, agencies which actively solicit material from free lance professionals and amateurs should be held to more stringent standards of liability. Any other rule would encourage controversy and handicap just and effective judicial administration of the "hot idea" industries.

\section{VERBAL ACTS AND IDEAS-THE COMMON SENSE OF FREE SPEECH}

Conviction for a breach of the peace may conceal a threat to the right of freedom of speech. The only cases in which the United States Supreme Court has been confronted by the presence of both concepts ${ }^{\mathrm{I}}$ did not require full exposition of their possible inconsistency. But a recent Tllinois decision, City of Chicago v. Terminiello, ${ }^{2}$ brings the question into sharp relief.

This problem, like any other involving the right of free speech, necessitates an understanding of the reasons that some speech is protected while other speech is punishable. The protection of the First Amendment may be invoked only when the words used are intended to convey ideas. Even though hostile in nature, these words will be protected because the "[u]ltimate good desire is better reached by free trade in ideas-that the test of truth is the power of the thought to get itself accepted in the competition of the market. ..."3

${ }^{30}$ For a development of the theory that thoughts are protected not so much for considerations of value but as instances "of the more general right of the individual to be let alone," see Brandeis and Warren, The Right to Privacy, 4 Harv. L. Rev. 193, 204-5 (I890). For a suggestion that abstract ideas are unprotected because a mere abstraction is not of sufficient value to society, see Logan, Legal Protection of Ideas, 4 Mo. L. Rev. 239, 240 (r939). But see $36 \mathrm{Col}$. L. Rev. $1375,{ }_{376}$ (1936), noting Grombach Productions, Inc. v. Waring, 293 N.Y. 609,59 N.E. 2 d 425 (I944), for the suggestion that ideas are not given the status of property because of the benefits to society from their free dissemination.

${ }^{37}$ See Caruthers v. RKO Radio Pictures, Inc., 20 F. Supp. 906, 908-9 (N.Y., 1937). The applicable section of the Copyright Act is 35 Stat. 1084 (I909), I7 U.S.C.A. § 40 (1937).

I Two important free speech cases have involved breach of peace prosecutions: Cantwell v. Connecticut, 310 U.S. 296 (1940); Chaplinsky v. New Hampshire, 3I5 U.S. 568 (1942); see also Cox v. New Hampshire, 312 U.S. 569 (194I).

2400 IIl. 23,79 N.E. $2 \mathrm{~d} 39$ (x 948 ).

3 Schenck v. United States, 249 U.S. 47,52 (Igrg). 